\title{
LIBERALIZM A INTERWENCJONIZM WOBEC RYNKU PRACY PRZYPADEK POLSKI JAKO KRAJU TRANSFORMUJĄCEGO SIĘ*
}

\begin{abstract}
WSTĘP
Celem artykułu jest analiza funkcjonowania rynku pracy i polityki gospodarczej wobec tego rynku w świetle doktryn liberalizmu ekonomicznego (w tym ordoliberalizmu) $\mathrm{i}$ interwencjonizmu państwowego, a następnie odniesienie tych ustaleń do koncepcji rynku pracy, jaka wykształciła się w transformującej się gospodarce polskiej. Przedmiotem zainteresowania są główne obszary sporu w traktowaniu zjawiska bezrobocia oraz $\mathrm{w}$ formułowaniu rekomendacji dla skali i sposobów interwencji państwa na rynku pracy.

Na podstawie powyższych ustaleń zostanie dokonana charakterystyka rynku pracy w Polsce po 1989 roku z uwzględnieniem osobliwości zachodzących w warunkach transformacji ustrojowej oraz skutków dla kształtowania się zatrudnienia i bezrobocia. Ponadto, pewnej ocenie poddane zostaną rozwiązania funkcjonalne $\mathrm{i}$ instytucjonalne związane z polityką państwa na rynku pracy w Polsce.
\end{abstract}

\section{DOKTRYNALNE PODSTAWY FUNKCJONOWANIA RYNKU PRACY I POLITYKI PAŃSTWA NA RYNKU PRACY}

\section{DZIAŁANIE RYNKU PRACY I ZJAWISKO BEZROBOCIA - PODSTAWOWE USTALENIA KIERUNKU NEOKLASYCZNEGO}

Ekonomiści klasyczni traktowali rynek pracy jako jeden $\mathrm{z}$ wielu rynków, na którym „spotyka się” popyt z podażą pracy i gdzie kształtuje się równowaga ryn-

* Praca powstała w ramach projektu badawczego własnego finansowanego przez MNiSW, pt. „Wpływ koncepcji liberalnych na proces transformacji gospodarczej w Polsce”, nr NN 112335534. 
kowa przy danej stawce płacy. Ale jednocześnie zdawali sobie sprawę ze specyfiki tego rynku, ze względu na wyjątkowy „przedmiot” transakcji, jakim jest praca, która była uznawana za najważniejszą przyczynę bogactwa narodów ${ }^{1}$.

Pierwsze teoretyczne ustalenia dotyczące rynku pracy były bardziej intuicyjne. I tak np. sformułowane przez J. S. Milla założenie o „maksimum współzawodnictwa" ${ }^{2}$ wobec funkcjonowania rynku pracy zostało dość powszechnie zaakceptowane przez neoklasyków (m.in. W. S. Jevonsa, L. Walrasa, A. Marshalla). Według J. S. Milla poziom płac zależy w najwyższym stopniu od relacji: popyt na pracę a liczba dostępnych pracowników³ ${ }^{3}$ Rynek pracy znajduje się w równowadze, a ewentualne bezrobocie jest wynikiem zbyt wysokiej płacy, nierównoważącej rynku. Wszyscy ci, którzy nie znajdują pracy - są bezrobotni dobrowolnie, gdyż płaca, której żądają, nie znajduje akceptacji wśród pracodawców.

Alfred Marshall identyfikował jeszcze inne przyczyny bezrobocia, takie jak: zmiany popytu na dobra, niedostatek „kapitału osobowego”, wahania koniunktu$r y^{4}$. W swoich określeniach rynku pracy wskazywał on na nietrwały, przejściowy charakter bezrobocia ${ }^{5}$.

Ekonomiści neoklasyczni wskazywali także na inne niedoskonałości mechanizmu rynkowego na rynku pracy ${ }^{6}$. A. C. Pigou za istotną przyczynę bezrobocia uznawał zbyt wysokie płace $\mathrm{w}$ stosunku do krańcowej wydajności pracy, a także niedopasowania struktury popytu na pracę do podaży pracy pod względem kwalifikacji i regionalnego rozmieszczenia ${ }^{7}$. W tego rodzaju identyfikowaniu przyczyn bezrobocia zarówno A. Marshall, jak i A. C. Pigou okazywali się prekursorami późniejszych ustaleń M. Friedmana i E. S. Phelpsa.

${ }^{1}$ Por. słowa A. Smitha: „bogactwo każdego narodu zależy od dwóch okoliczności: po pierwsze od umiejętności, sprawności i znawstwa, z jakim swą pracę zazwyczaj wykonuje; po drugie, od stosunku liczby tych, którzy pracują użytecznie, do liczby tych, którzy tego nie czynią". A. Smith, Badania nad natura i przyczynami bogactwa narodów, t. 1, Państwowe Wydawnictwo Naukowe, Warszawa 1954, s. 3.

${ }^{2}$ Założenie o „maksimum współzawodnictwa” sformułowane przez J. S. Milla było stosowane przez niego do analizy wszystkich rynków, nie tylko pracy. Traktował je jako ważne założenie, konstytuujące model homo oeconomicus w teorii ekonomii. Szerzej: K. Szarzec, Racjonalny podmiot gospodarczy w klasycznej myśli ekonomicznej i jej wspótczesnych kontynuacjach, PTE-PFAKE, Warszawa 2005, s. 56.

${ }^{3}$, „[... ] współzawodnictwo musi być uważane w obecnym stanie społecznym za głównego regulatora płac, a zwyczaj i jednostkowe cechy tylko za okoliczności modyfikujące i to w stosunkowo nieznacznym stopniu”. J. S. Mill, Zasady ekonomii politycznej i niektóre jej zastosowania do filozofii spotecznej, t. 1, PWN, Warszawa 1965, s. 535. Por. także: ibidem, s. 536, 538.

${ }^{4}$ Szerzej o przyczynach bezrobocia i zestawieniu ich ze współczesnymi koncepcjami bezrobocia zob.: J. Dzionek-Kozłowska, System ekonomiczno-spoteczny Alfreda Marshalla, Wydawnictwo Naukowe PWN, Warszawa 2007, s. 374-380.

${ }^{5}$ Szerzej: ibidem, s. 367-374.

${ }^{6}$ Szerzej: D. Kotlorz, U. Zagóra-Jonszta, Rynek pracy w teorii i praktyce, Wydawnictwo Uczelniane Akademii Ekonomicznej w Katowicach, Katowice 1998, s. 46 i nast.

${ }^{7}$ Por. E. Kwiatkowski, Neoklasyczne teorie zatrudnienia, PWN, Warszawa 1988, s. 43. 
Kontynuatorzy myśli neoklasycznej (szkoły: monetarystyczna, nowa ekonomia klasyczna i realnego cyklu koniunkturalnego) podtrzymują tezę o sprawnym działaniu mechanizmu rynkowego i dobrowolnym charakterze bezrobocia. Jednakże samo pojmowanie kwestii równowagi rynku pracy i bezrobocia zostaje przez nich w istotny sposób rozwinięte i zmodyfikowane.

Według M. Friedmana i E. S. Phelpsa bezrobocie stanowi immanentną cechę rynku pracy. Ten rodzaj bezrobocia nazwany zostaje naturalnym (lub bezrobociem równowagi), z podkreśleniem jego „dobrowolnego” charakteru ${ }^{8}$. Struktura tego bezrobocia (determinują uwarunkowania): strukturalne ${ }^{9}$ (wynikające $\mathrm{z}$ niedopasowania struktury popytu na pracę do podaży pracy), instytucjonalne ${ }^{10}$ (będące wynikiem specyficznych relacji między pracownikami i pracodawcami oraz państwem) i frykcyjne (powstające wskutek zmian pracy przez osoby poszukujące nowego, lepiej płatnego zatrudnienia). Poziom bezrobocia naturalnego nie zależy od czynników pieniężnych, lecz od realnych, takich jak: efektywność działania rynku pracy, poziom konkurencji czy monopolu, trudności lub ułatwienia w przekwalifikowaniu się bezrobotnych. Naturalna stopa bezrobocia jest więc swoistą „kotwicą”, do której dąży rynek pracy w równowadze. Polityka państwa wobec rynku pracy powinna być skoncentrowana wokół oddziaływania na stronę podażową, w tym poprzez usprawnienie systemu przepływu informacji o miejscach pracy, zwiększenie mobilności pracowników, dostosowanie systemu kształcenia i przekwalifikowania do zmieniających się potrzeb w gospodarce itp.

\section{FUNKCJONOWANIE RYNKU PRACY I BEZROBOCIE W UJĘCIU KIERUNKU KEYNESOWSKIEGO}

Wykształcenie się kierunku keynesowskiego w latach 30. XX wieku związane było z pracami J. M. Keynesa, który zakwestionował klasyczną tezę o samoregulacji i efektywności mechanizmu rynkowego. Wskazywał on m.in. na wysoką niestabilność inwestycji w gospodarce, co wiązało się z tym, że efektywny popyt globalny ustalał się często na poziomie niższym od popytu zapewniającego pełne zatrudnienie. Wynikał z tego wniosek o niezdolności gospodarki do osiągnięcia stanu pełnego zatrudnienia. Zasadny stawał się postulat aktywnego działania

${ }^{8}$ Szerzej na temat rodzajów bezrobocia wyróżnianych w ramach bezrobocia naturalnego zob. w: W. Jarmołowicz, B. Woźniak, Bezrobocie równowagi a polityka państwa na rynku pracy, [w:] D. Kopycińska (red.), Teoretyczne aspekty gospodarowania, Uniwersytet Szczeciński, Szczecin 2005.

${ }^{9}$ Szerzej o koncepcji strukturalistycznej bezrobocia zob. w: ibidem, s. 60-61.

${ }^{10}$ Por. W. Jarmołowicz, B. Woźniak, Polityka rynku państwa wobec bezrobocia, „Zeszyty Naukowe Polskiego Towarzystwa Ekonomicznego w Krakowie”, Kraków 2006, nr 4, s. 113-129. 
państwa poprzez pobudzanie popytu globalnego. Występujące bezrobocie nazwane zostało „przymusowym”.

Pojęcie „przymusowe” w odniesieniu do bezrobotnych wskazuje jednocześnie na niemożliwość zmiany tej sytuacji przez indywidualnego bezrobotnego i „ucieczki” od bezrobocia. Ani bowiem przekwalifikowanie, ani większa mobilność, ani nawet akceptacja niższej płacy - nie zmienią pozycji bezrobotnego. Najskuteczniejszym sposobem przeciwdziałania takiemu bezrobociu jest polityka wpływająca na wzrost popytu globalnego, głównie - ekspansywna polityka fiskalna.

Polityka pobudzania koniunktury i ograniczania bezrobocia przymusowego zaproponowana przez J. M. Keynesa stanowiła tym samym „rewolucyjną” negację ustaleń ekonomii klasycznej i neoklasycznej. Co więcej, okazała się ona - w okresie powojennym - stosunkowo skuteczna, i to do końca lat 60 . XX wieku.

We współczesnych modelach neokeynesowskich ${ }^{11}$ teza o bezrobociu przymusowym jest nadal utrzymywana. Jest ona jednakże precyzyjniej objaśniana poprzez odwołanie się do hipotezy płac wydajnościowych oraz sztywności nominalnych cen i płac. Według tej pierwszej, pracodawca ustala stawkę płacy tak, aby zminimalizować koszt pracy na jednostkę wydajności (jest to nazywane płacą wydajnościową ${ }^{12}$. Zatrudnia on dodatkowych pracowników aż do momentu, kiedy przychód marginalny produktu jest równy ustalonej przez niego - zgodnie z płacą wydajnościową - realnej płacy. Płaca realna może przy tym być wyższa niż krańcowa produktywność pracy i płaca równowagi. Pracodawca czyni tak, bo uważa, że obniżka płac realnych do poziomu płacy równowagi może negatywnie wpłynąć na poziom wydajności jego pracowników.

Wyższa płaca uzasadniana jest ${ }^{13}$ : brakiem skłonności pracowników do „bumelowania" i do odejścia z przedsiębiorstwa, trudnościami z zatrudnieniem nowych, odpowiednich pracowników oraz istniejącymi społecznymi normami zachowań pracowników i pracodawców. Wyższe koszty ponoszone przez producenta (jeśli oferowana płaca realna jest wyższa od krańcowej produktywności pracy) nie oznaczają przy tym dla niego odpowiednio większych strat, bo te - przynajmniej częściowo - są rekompensowane przez wzrost wydajności pracowników.

Tak uzasadnione sztywności płac stają się istotnym powodem występowania bezrobocia przymusowego. Oznacza to tym samym, że zawsze istnieją wolne

${ }^{11}$ Por. model G. A. Akerlof i J. L. Yellen w: G. A. Akerlof, J. L. Yellen, A Near-Rational Model of the Business Cycle, with Wage and Price Inertia, [w:] N. G. Mankiw, D. Romer (red.), New Keynesian Economics, vol. 1: Imperfect Competition and Sticky Prices, MIT Press, Cambridge 1991.

${ }^{12}$ Szerzej: E. Kwiatkowski, Bezrobocie. Podstawy teoretyczne, Wydawnictwo Naukowe PWN, Warszawa 2002, s. 179 i nast.

${ }^{13}$ Szerzej: J. L. Yellen, Efficiency Wage Models of Unemployment, „American Economic Review”, May 1984, vol. 74, no. 2. 
moce, które mogą zostać wykorzystane, jeśli tylko producenci zwiększą produkcję i popyt na pracę.

\section{STANOWISKO ORDOLIBERALNE A ZATRUDNIENIE I BEZROBOCIE}

Początki doktryny ordoliberalnej sięgają lat 30. XX wieku, ale jej rozkwit przypada na okres po II wojnie światowej, kiedy to zastosowana została w powojennych Niemczech. Ordoliberałowie, tacy jak W. Eucken, A. Müller-Armack czy L. Erhard, szukali „trzeciej” drogi pomiędzy współczesnym im dychotomicznym podziałem ustrojów gospodarczych na gospodarkę rynkową i gospodarkę centralnie zarządzaną, a także pomiędzy programem polityki gospodarczej postulowanym przez ekonomię neoklasyczną a teorią keynesowską ${ }^{14}$. Dążyli oni do zaznaczenia swojej odrębności, także doktrynalnej. Ordoliberałowie opowiadali się jednoznacznie za gospodarką rynkową, proponując pewne jej modyfikacje zarówno w stosunku do doktryny leseferyzmu, jak i keynesizmu. W odniesieniu do sporu pomiędzy neoklasykami a J. M. Keynesem, W. Eucken krytykował tych pierwszych za nadmierny leseferyzm i doprowadzenie do kartelizacji gospodarki, a J. M. Keynesa - za przesadny i źle pojmowany interwencjonizm państwowy w działaniach na rzecz pełnego zatrudnienia ${ }^{15}$. Dla ordoliberałów bowiem ingerencja państwa w gospodarkę miała być głównie środkiem do przywrócenia i utrzymania wolnej konkurencji ${ }^{16}$. Głównym zadaniem państwa jest tworzenie warunków i form porządkujących gospodarkę rynkową, co nazwano „polityką kształtowania ładu gospodarczego"17. Doktryna ordoliberalna wypracowała pewien model funkcjonowania rynku pracy oraz rekomendacje dla polityki państwa. Egzemplifikacją tego był rzeczywisty rynek pracy w powojennej Republice Federalnej Niemiec, zwłaszcza za rządów L. Erharda.

${ }^{14}$ Jak pisał A. Müller-Armack w 1947 r.: „obydwa alternatywne systemy, które dotychczas miała do dyspozycji polityka gospodarcza, tj. system czysto liberalnej gospodarki rynkowej i system gospodarki sterowanej, są wewnętrznie wypalone, stąd też niezbędne jest rozwinięcie nowej, trzeciej formy, która jednak nie może być jedynie jakąś mglistą mieszanką systemową, wyrazem kompromisu partyjnego, lecz powinna stanowić syntetyczną koncepcję, uwzględniającą współczesne uwarunkowania”. A. Müller-Armack, Sterowanie gospodarkq a gospodarka rynkowa. Konieczność nowej formy polityki gospodarczej, [w:] E. Mączyńska, P. Pysz (red.), Spoteczna gospodarka rynkowa. Idee i możliwości praktycznego wykorzystania w Polsce, PTE, Warszawa 2003, s. 38.

${ }^{15}$ Por.: W. Eucken, Podstawy polityki gospodarczej, Wydawnictwo Poznańskie, Poznań 2005, s. $179-183$.

${ }^{16}$ U. Zagóra-Jonszta, Ordoliberalizm a spoteczna gospodarka rynkowa Niemiec. Możliwości jej realizacji w Polsce, Wydawnictwo Uczelniane Akademii Ekonomicznej w Katowicach, Katowice 1999, s. 29-30.

${ }_{17}$ Por. J. Czech-Rogosz, Ordoliberalna koncepcja tadu gospodarczego, [w:] B. Polszakiewicz, J. Boehlke (red.), Ead instytucjonalny w gospodarce, Wydawnictwo UMK, Toruń 2005, s. 115-116. 
Zdaniem ordoliberałów bezrobocie - zwłaszcza masowe - to wielki problem nie tylko ekonomiczny, ale też społeczny i polityczny. W. Eucken identyfikuje wiele jego przyczyn, $\mathrm{w} \operatorname{tym}^{18}$ : niedopasowania strukturalne o charakterze regionalnym, ulepszenia technologiczne, źle działający system płac i cen, nadmierną ekspansję monetarną, a także - częściowy monopol związków zawodowych. Problemem rynku pracy jest też „monopol nabywcy”" ${ }^{19}$, który może występować w pewnych gałęziach gospodarki czy regionach kraju. Wówczas to pracodawcy-monopoliści oferują niższą płacę od tej wynikającej z krańcowej produktywności pracownika. W takiej sytuacji konieczna jest ingerencja państwa.

Wizja „dobrobytu dla wszystkich” proponowana przez L. Erharda, którą miała zapewnić odpowiednia polityka gospodarcza na rynku pracy, obejmowała realizację postulatu pełnego zatrudnienia ${ }^{20}$ poprzez stworzenie warunków równego i swobodnego dostępu do rynku pracy oraz do uzyskiwania dochodów zarówno z pracy, jak i kapitału. Państwo - zdaniem ordoliberałów - winno też przeciwdziałać wykluczeniu jednostek z rynku pracy, a jeśli to się nie udaje - świadczyć bardziej rozwiniętą pomoc społeczną. Zapewnienie zatem swobodnego dostępu do rynku pracy oraz prawa do bogacenia się z efektów pracy i kapitału jest niezbędne po to, aby - jak pisał L. Erhard - „udało się wreszcie przezwyciężyć ten hamujący postęp, stan rzeczy i jednocześnie wraz z tym antagonizmy pomiędzy biednymi i bogatymi" 21 .

W Niemczech przyjęto dla realizacji tego celu koncepcję „polityki ustrojowej opartej na stanach zawodowych"22, w której ważną rolę odgrywają instytucje samorządowe oraz stany zawodowe. Rząd L. Erharda utrzymywał dobre stosunki ze związkami zawodowymi, czego rezultatem był brak sytuacji wymuszeń przez związki możliwie najwyższych podwyżek płacy $^{23}$. Między pracodawcami a związkami dochodziło też do popieranych przez rząd negocjacji, w wyniku których ustalano minimalne poziomy wynagrodzenia (faktyczne wynagrodzenie było $\mathrm{z}$ reguły wyższe od minimalnego). Inną cechą niemieckiego rynku pracy stał się udział pracownika w procesie podejmowania decyzji gospodarczych i społecznych na trzech poziomach: przedsiębiorstw, branż i całej gospodarki ${ }^{24}$. Negocjowanie

${ }^{18}$ Por. W. Eucken, op. cit., s. 87-88.

${ }^{19}$ Ibidem, s. 86.

${ }^{20}$ Por. P. Pysz, Ordoliberalna koncepcja tadu instytucjonalnego w gospodarce, [w:] B. Polszakiewicz, J. Boehlke (red.), Ead instytucjonalny..., s. 146-147.

${ }^{21}$ L. Erhard, Wohlstand für alle, wyd. 8, Econ Verlag, Düsseldorf-Wien 1964, s. 9, cyt. za: ibidem, s. 146-147.

${ }^{22}$ W. Eucken, op. cit., s. 184.

${ }^{23}$ Por. H. F. Wünsche, Spoteczna gospodarka rynkowa - legendarny niemiecki "cud gospodarczy” a aktualne problemy polityki gospodarczej Niemiec, [w:] Spoteczna gospodarka rynkowa..., s. 116.

${ }^{24}$ Por. T. Kowalik, Spoteczna gospodarka rynkowa-dekoracja czy program dziatania?, [w:] Spoteczna gospodarka rynkowa..., s. 141. 
i zawieranie umów na poziomie branży i całej gospodarki krajowej prowadzone było głównie pomiędzy związkami zawodowymi a organizacjami pracodawców. Wewnątrz przedsiębiorstw działały różne przedstawicielstwa załóg, które brały udział we współrządzeniu. Jedną z nich są rady zakładowe, wybierane przez pracowników, które mają w szczególności duże uprawnienia w zakresie polityki zatrudnienia ${ }^{25}$. Chociaż po odejściu L. Erharda w 1966 roku z rządu w Niemczech prowadzono bardziej „keynesowską” politykę gospodarczą (czego wyrazem było przyjęcie Ustawy o wzroście i stabilizacji gospodarczej w $1967 \mathrm{r}^{26}$ ), to jednak zasadnicze „ramy” rynku pracy pozostały ${ }^{27}$.

Według ordoliberałów państwo powinno działać na rzecz równego dla wszystkich dostępu do rynku pracy. To, czy jednostka zaakceptuje dane warunki pracy i płacy, pozostanie jej wolnym wyborem. W koncepcji ordoliberałów kluczowe miejsce zajmują wolność i odpowiedzialność jednostki gospodarującej. Można więc stwierdzić, że ordoliberałowie traktują bezrobocie również jako „dobrowolne”. Kiedy jednak przyjmuje ono charakter masowy, wówczas zasadna staje się ingerencja państwa, ale nie w postaci keynesowskiej polityki popytowej. Pożądane i postulowane są rozwiązania systemowe, które nakierowane są bardziej na stronę podażową rynku pracy, co tym samym przybliża stanowisko ordoliberałów do neoliberałów. Dostrzegając „trudność” bycia bezrobotnym (także z powodu utraty dochodów), ordoliberałowie skłonni są do bardziej „hojnej” polityki społecznej, co z kolei zbliża ich w tym zakresie do socjaldemokratów.

\section{CHARAKTERYSTYKA RYNKU PRACY W POLSCE - ASPEKTY FUNKCJONALNE I INSTYTUCJONALNE}

\section{RYNEK PRACY I BEZROBOCIE W POLSCE W LATACH 1990-2009}

Istotą przekształceń ustrojowych, zapoczątkowanych w Polsce i innych krajach Europy Środkowo-Wschodniej po 1989 roku, było przejście od systemu gospodarki centralnie zarządzanej do systemu gospodarki rynkowej. Przekształcenia te objęły również rynek pracy, powodując radykalne zmiany w zakresie racjonalizacji i restrukturyzacji zatrudnienia. Już w pierwszym roku przemian rozpoczął się systematyczny spadek zatrudnienia w gospodarce, a zmiana reguł gospo-

${ }^{25}$ Szerzej ibidem, s. 141-143.

${ }^{26}$ Szerzej H. F. Wünsche, op. cit., s. 118-120.

${ }^{27}$ Por. A. Czech, U. Zagóra-Jonszta, Niemiecki neoliberalizm jako teoretyczny fundament spotecznej gospodarki rynkowej (powstanie, odniesienia, recepcja), [w:] Spoteczna gospodarka rynkowa..., s. 184; U. Zagóra-Jonszta, op. cit., s. 62-63; T. Kowalik, Systemy gospodarcze. Efekty i defekty reform $i$ zmian ustrojowych, Fundacja Innowacja, Warszawa 2005, s. 139-145. 
darowania przekształciła rynek pracy ze stanu nierównowagi popytowej w stan nierównowagi podażowej ${ }^{28}$. Pojawiło się też nieznane w gospodarce centralnie planowanej - zjawisko jawnego bezrobocia. Stało się ono przy tym trwałym i nieodłącznym - choć zróżnicowanym co do wielkości - elementem funkcjonowania gospodarki rynkowej w Polsce. Wśród pierwszych przyczyn bezrobocia można wskazać na: głęboki spadek produkcji wywołany restrykcyjnym programem stabilizacyjnym, restrukturyzację gospodarki i redukcję bezrobocia ukrytego, pasywne zachowania osób zwalnianych w warunkach liberalnego przyznawania zasiłków dla bezrobotnych, wejście na rynek pracy wyżu demograficznego, niedopasowanie systemu kształcenia oraz pośrednictwa pracy do potrzeb rynku itp. W efekcie tego na koniec I kwartału 1994 roku co szósty aktywny zawodowo Polak pozostawał bez pracy (por. dane na rys. 1).

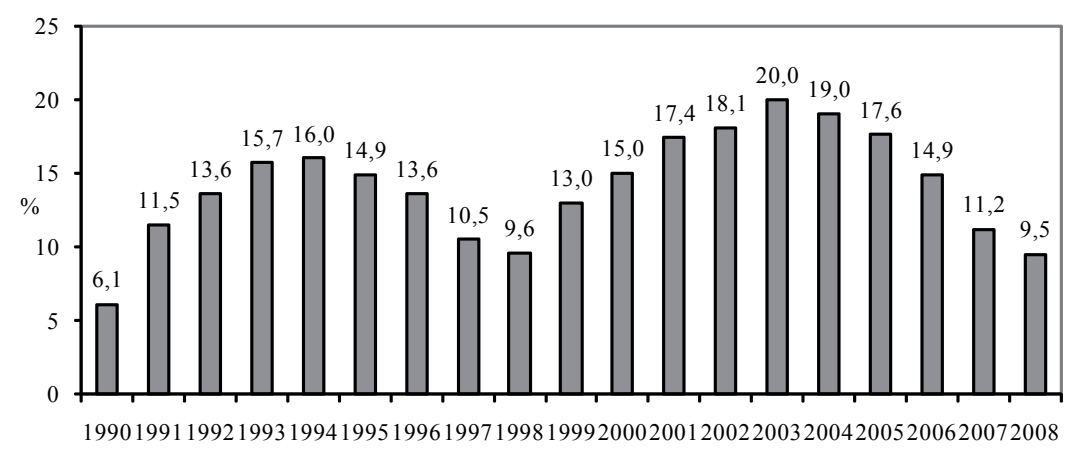

Rysunek 1. Stopa bezrobocia rejestrowanego w Polsce w latach 1990-2008 Źródło: GUS.

W latach 1994-1998 obserwowano spadek stopy bezrobocia (z 16,7\% w pierwszym kwartale 1994 roku do 9,6\% na koniec 1998 roku), co było związane $z$ szybkim rocznym wzrostem PKB. Jednak wraz z osłabieniem tempa wzrostu gospodarczego bezrobocie po 1999 roku zaczęło ponownie wzrastać. Było ono wywołane m.in. dalszą racjonalizacją zatrudnienia, zmianami strukturalnymi na rynkach produktu i pracy, wzrostem wydajności, rosnącymi płacowymi i pozapłacowymi kosztami pracy, zwiększającą się nieelastycznością rynku pracy, jak

${ }^{28}$ Por. D. Piątek, J. Kornai'a modele nierównowagi na rynku pracy i ich implikacje dla procesu transformacji, [w:] W. Jarmołowicz (red.), Rynek pracy w warunkach zmian ustrojowych, Wydawnictwo AE w Poznaniu, Poznań 2003, s. 13-25. 
również i tym, że wzrost gospodarczy stawał się w coraz większym stopniu „bezzatrudnieniowy"29.

W latach 2003-2008 odnotowano szybsze tempo wzrostu PKB, któremu towarzyszył wyraźny spadek stopy bezrobocia. Na sytuację na rynku pracy miała także wpływ migracja zarobkowa Polaków do niektórych krajów Unii Europejskiej.

W 2008 roku po raz pierwszy od 10 lat stopa bezrobocia była na poziomie jednocyfrowym. Jednak z początkiem roku 2009 roku zaczęło przybywać nowych bezrobotnych rejestrujących się w urzędach pracy. Na koniec sierpnia 2009 roku bezrobotni zarejestrowani w urzędach pracy stanowili 10,8\% cywilnej ludności aktywnej zawodowo. Charakterystyczną właściwością polskiego rynku pracy pozostają: niskie poziomy wskaźnika zatrudnienia ${ }^{30}$, wysoki poziom bezrobocia strukturalnego w przekroju zawodowym ${ }^{31}$ oraz wysoki poziom bezrobocia ukrytego w rolnictwie.

Bezrobocie w Polsce ma charakter złożony. Uwzględniając jego główne przyczyny, ma ono charakter strukturalny, a - w okresie dekoniunktury - koniunkturalny. Ponadto w gospodarkach krajów transformujących się należy także wyróżnić bezrobocie transformacyjne ${ }^{32}$, które jest wynikiem dokonywanych przekształceń systemowych. Jego geneza bierze się z występowania w gospodarce centralnie zarządzanej tendencji do powstania nadmiernego zatrudnienia. W okresie zasadniczych przekształceń systemowych, polegających na reorientacji celów i zasad funkcjonowania podmiotów gospodarujących, następuje dopasowanie popytu na pracę do wymogów ekonomicznej racjonalności działania tych podmiotów, w konsekwencji czego - nagromadzone zasoby nadmiernego zatrudnienia ulegaja redukcji. W związku z tym redukcja takiego bezrobocia może być trudniejsza niż w rozwiniętej gospodarce rynkowej. Wymaga bowiem trudniejszego do osiagnięcia stanu ukształtowania się odpowiednich wielkości determinujących popyt na pracę oraz jej podaż (jak np. dynamika wzrostu PKB, tempo wzrostu płac i produkcyjności pracy itp. $)^{33}$. W szczególności ważne jest dokonanie odpowiednich przekształceń instytucjonalnych i funkcjonalnych, „nadających” danej gospodarce transformującej się cechy i właściwości odpowiednie do uznania jej za rynkową.

${ }^{29}$ Por. E. Kwiatkowski, S. Roszkowska, T. Tokarski, Granice wzrostu bezzatrudnieniowego w Europie i krajach WNP, „Ekonomista” 2004, nr 1, s. 52.

${ }^{30}$ Szerzej M. Baron-Wiaterek, Instytucjonalno-prawne aspekty rynku pracy i promocji zatrudnienia, IPiSS, Warszawa 2008, s. 43-44.

${ }^{31}$ L. Kucharski, K. Myślińska, Poziom niedopasowań strukturalnych na rynku pracy w Polsce, [w:] S. Krajewski, A. Stępniak-Kucharska (red.), Polska po 15 latach. Efekty transformacji, „Folia Oeconomica”, nr 219, Wydawnictwo Uniwersytetu Łódzkiego, Łódź 2008, s. 51-67.

32 Por. W. Jarmołowicz, B. Woźniak, Bezrobocie równowagi a polityka państwa wobec rynku pracy, [w:] J. Ostaszewski (red.), Bezrobocie w Polsce - diagnoza sytuacji. Pożq̨dane kierunki w ograniczaniu bezrobocia, SGH, Warszawa 2006, s. 122.

${ }^{33}$ Por. E. Kwiatkowski, op. cit., s. 17. 
W ramach ogólnej kategorii bezrobocia transformacyjnego wyróżnia się bezrobocie strukturalne i instytucjonalne. Niedopasowania strukturalne w kraju transformującym się warunkowane są oddziaływaniem szczególnych, społecznoekonomicznych czynników, wywołanych przez przekształcenia ustrojowe. Powodują one zmiany w strukturze kwalifikacyjnej, gałęziowej i regionalnej popytu na pracę i podaży pracy, i to wyraźnie odmienne od tych, jakie występowałyby w warunkach funkcjonowania „względnie ustabilizowanej” (choć także przecież podlegającej przekształceniom strukturalnym) gospodarki rynkowej. Ich skutkiem jest właśnie transformujące się bezrobocie strukturalne. Ograniczenie tego rodzaju bezrobocia wymaga kosztownych i długotrwałych procesów przystosowawczych, polegających głównie na zasadniczym odejściu od struktury cechującej gospodarkę centralnie zarządzaną do struktury właściwej gospodarce o trwałej orientacji rynkowej.

Z kolei przyczyną instytucjonalnego bezrobocia transformacyjnego są takie zmiany ustrojowe w gospodarce transformującej się, które wpływają na usztywnienie płac w dół i brak zainteresowania - po stronie przedsiębiorstw - obniżaniem bezrobocia poprzez oferowanie niższych wynagrodzeń. Ponadto w okresie transformacji ma miejsce proces likwidacji „starych” instytucji i tworzenia „nowych”, co także wpływa znacząco na relacje pomiędzy pracodawcami a pracownikami. Przykładem może być w prywatyzowanym przedsiębiorstwie przyjmowanie „pakietu socjalnego" uniemożliwiającego jednocześnie (przynajmniej przez pewien okres) wprowadzenie takich zmian w poziomie i strukturze zatrudnienia (a także w płacach), które pozwoliłyby przedsiębiorstwu na swobodne funkcjonowanie.

Po stronie podaży pracy na wielkość i strukturę tego rodzaju bezrobocia może wpływać zachowanie samych bezrobotnych spowodowane zmianami „formalnoprawnymi” ich statusu bezrobotnego. Przykładem tego są zmiany „definicji” bezrobotnego w ustawodawstwie (jak było w Polsce) czy uprawnień socjalnych (zasi1ki dla bezrobotnych, renty chorobowe, zasiłki i świadczenia przedemerytalne) ${ }^{34}$.

\section{POLITYKA PAŃSTWA NA RYNKU PRACY - ELEMENTY OCENY}

Dynamiczne i radykalne zmiany na polskim rynku pracy okresu transformacji gospodarczej wymuszały $-\mathrm{z}$ jednej strony - potrzebę dostosowania polityki gospodarczej do zakładanych i realizowanych celów w zakresie stabilizacji makroekonomicznej oraz przekształceń społeczno-ustrojowych, a z drugiej- do takiego oddziaływania państwa na rynek pracy, aby podnosząc produktywność pracy,

${ }^{34}$ Szerzej: W. Jarmołowicz, B. Woźniak, Bezrobocie nierównowagi a polityka państwa na rynku pracy, [w:] W. Jarmołowicz (red.), Funkcjonowanie gospodarki rynkowej w Polsce. Aspekty makroi mikroekonomiczne, Wydawnictwo AE w Poznaniu, Poznań 2005, s. 34-35. 
przeciwdziałać równocześnie spadającemu zatrudnieniu, jak też zwalczać wysokie bezrobocie.

$\mathrm{O}$ ile przy tym cele stabilizacyjne i przekształceniowe wiązały się z prowadzoną polityką makroekonomiczną, o tyle oddziaływanie bezpośrednio na rynek pracy pozostawało $\mathrm{w}$ orbicie zainteresowań polityki zatrudnienia i rynku pracy ${ }^{35}$. Ta pierwsza ma na celu przede wszystkim tworzenie nowych miejsc pracy m.in. poprzez stymulowanie rozwoju przedsiębiorczości oraz bardziej produktywne wykorzystanie występujących w gospodarce zasobów pracy, w tym poprzez zwiększenie aktywizacji zawodowej ludności. $Z$ kolei polityka rynku pracy dotyczy głównie ograniczania i przezwyciężania bezrobocia poprzez aktywizację samych bezrobotnych, jak też łagodzenia jego ekonomicznych i społecznych dolegliwości. W szczególności realizowaną w Polsce politykę rynku pracy dzieli się zwykle na aktywną (jako dążącą do osiągania celów pozazatrudnieniowych i strukturalnych w rozumieniu pełniejszego i lepszego dostosowania potencjału bezrobotnych do potrzeb gospodarki) oraz pasywną (służącą głównie ochronie socjalnej) ${ }^{36}$. Polityka zatrudnienia jako zmierzająca bardziej do pobudzania wzrostu gospodarczego i przeciwdziałania dekoniunkturze to polityka odwołująca się w istotnym stopniu do zaleceń i dorobku keynesizmu. Natomiast polityka rynku pracy jako sprzyjająca bardziej przepływowi informacji, mobilności i poprawie kwalifikacji bezrobotnych, czyli uelastycznieniu i deregulacji rynku pracy, jest głównie podkreślana przez przedstawicieli kierunku neoklasycznego, jak też i ordoliberalnego. Obie te polityki wymagają rozwoju wielu nowych publicznych, jak i niepublicznych instytucji (formalnych i nieformalnych) na rynku pracy.

Próbując ocenić politykę na rynku pracy w Polsce, należy wskazać na następujące jej uwarunkowania i właściwości:

a) Zachodzący proces transformacji gospodarki w Polsce, wymagał wprowadzenia „nowej polityki gospodarczej” pojętej jako oddziaływanie państwa na zachowania różnych podmiotów (w tym także zróżnicowanych rodzajowo, jak i własnościowo) w nowo kształtującej się rzeczywistości „rynkowej” (związanej z wolnością wyboru w zakresie konsumpcji i produkcji oraz z utratą przez państwo dominującej pozycji właścicielskiej).

35 Szerzej: W. Jarmołowicz, Państwo jako podmiot polityki gospodarczej na rynku pracy, [w:] W. Jarmołowicz, M. Knapińska (red.), Polityka państwa na rynku pracy w warunkach transformacji $i$ integracji gospodarczej, Wydawnictwo Akademii Ekonomicznej, Poznań 2005. Por. także: W. Jarmołowicz, B. Woźniak, Bezrobocie równowagi i nierównowagi a polityka gospodarcza państwa, [w:] T. Listwan, W. Kaczocha (red.), Wspótczesne przemiany spoteczno-gospodarcze w Polsce i na świecie, Wydawnictwo Forum Naukowe, Poznań 2007, s. 162 i nast.

${ }^{36}$ Szerzej: W. Jarmołowicz, M. Knapińska, Podmioty, cele i instrumenty polityki państwa na rynku pracy, [w:] W. Jarmołowicz, M. Knapińska (red.), Polityka państwa na rynku pracy w warunkach transformacji i integracji gospodarczej, Wydawnictwo Akademii Ekonomicznej, Poznań 2005. 
b) W odniesieniu do rynku pracy prowadzona jest zarówno polityka makroekonomiczna, jak i mikroekonomiczna. Na jego rozwój mają także wpływ polityka ustrojowa (systemowa) oraz związana z przekształceniami własnościowymi i instytucjonalnymi.

c) Wykorzystywanie różnych typów i rodzajów polityki gospodarczej było „naznaczone" strategią transformacji odwołującą się przede wszystkim do radykalizmu, a nie gradualizmu. Wskutek tego na rynku pracy pojawiły się „koszty społeczne” w postaci bezrobocia, ale też „korzystne efekty ekonomiczne” związane $z$ racjonalizacją zatrudnienia i wzrostu wydajności pracy.

d) Istotny wpływ na kierunki i sposoby prowadzenia polityki gospodarczej miały rezultaty „ścierania” się koncepcji liberalizmu i interwencjonizmu gospodarczego. Wydaje się, że wpływ tej pierwszej był wyraźnie silniejszy w latach 90. (tj. w okresie tworzenia „podstaw” gospodarki rynkowej), a tej drugiej w pierwszej dekadzie XXI wieku (tj. w okresie działania już ukształtowanej gospodarki rynkowej, choć jeszcze podlegającej pewnym modyfikacjom ze względu na jej model ustrojowy).

e) Przy występowaniu wielu specyficznych „właściwości” charakterystycznych dla gospodarek transformujących się w porównaniu do gospodarek krajów wysoko rozwiniętych, jak też niemożliwości „pełnej implementacji” rozwiązań funkcjonalnych i instytucjonalnych wyrosłych $z$ doświadczeń krajów rynkowych, zasadne było szczególne traktowanie w polityce gospodarczej państwa realizacji postulatu „pełnego zatrudnienia” (tj. jako akceptującego jednak pewien poziom bezrobocia "naturalnego”), jak też zwalczania bezrobocia strukturalnego i instytucjonalnego o charakterze także transformacyjnym.

f) Istotny wpływ na politykę na rynku pracy w Polsce wywierały działania związane z akcesją do Unii Europejskiej. Obejmowały one przede wszystkim dostosowanie prawodawstwa w zakresie pracy i implementację Europejskiej Strategii Zatrudnienia. Od momentu wejścia Polski do UE istotny wpływ na tę politykę mają kwestie związane ze swobodnym przepływem osób, jak i z absorpcją funduszy strukturalnych, zwłaszcza środków z Europejskiego Funduszu Społecznego.

g) Ważne znaczenie dla rynku pracy i sytuacji bezrobotnych mają także różnego rodzaju świadczenia socjalne na rzecz bezrobotnych, związane z pasywną polityką rynku pracy, jak i polityką społeczną w ogóle (w postaci zasiłków, odpraw z racji zwolnień, wcześniejszych emerytur, zachowania opieki zdrowotnej itp.).

Mimo tego, że po okresie „zwiększonej hojności” państwa w początkach transformacji zakresy i formy świadczeń dla bezrobotnych ulegały stopniowo wyraźnemu ograniczaniu, to można jednak zauważyć, że w warunkach wcześniejszej 
(wywodzącej się z gospodarki centralnej) rozbudowanej polityki socjalnej oraz w sytuacji wzmożonych potrzeb „osłonowych” (wynikających z dokonującej się transformacji) politykę gospodarczą i społeczną państwa należałoby uznać (pod względem jej rozwiązań funkcjonalnych i instytucjonalnych) za bliższą jednak tradycjom socjaldemokratycznym i ordoliberalnym aniżeli liberalnym (sensu stricto).

\section{LIBERALISM VERSUS INTERVENTIONISM TO THE LABOUR MARKET. THE CASE OF POLAND AS A TRANSITION COUNTRY}

SUMMARY

An objective of this paper is to compare views of liberal economy and interventionism to a labour market and labour market policy. It is a ground for discussing the concept of the labour market in a transition economy. Based on the literature, the main divergences and arguments for intervention in the labour market are presented, with an emhasis put on liberalism, ordoliberalism and the Keynesian doctrine. The Polish labour market and labour market policy were analyzed in 1990-2008. 
